\title{
Studies on the Nutritional Status of School Age Children in Drought Affected Desert Environment of Western Rajasthan, India
}

\author{
Singh $\mathrm{MB}^{*}$ and Fotedar $\mathrm{R}$
}

Desert Medicine Research Centre, New Pali Road, Jodhpur, India

*Corresponding author: Singh MB, Desert Medicine Research Centre, New Pali Road, Jodhpur, India, Fax: +91-291-2720618, Tel: +91-291-2744616, E-mail: mbsgh@yahoo.com

Citation: Singh MB, Fotedar R (2015) Studies on the Nutritional Status of School Age Children in Drought Affected Desert Environment of Western Rajasthan, India. J Nutr Health Sci 2(2): 202. doi: 10.15744/23939060.2.202

Received Date: February 16, 2015 Accepted Date: May 18, 2015 Published Date: May 20, 2015

\begin{abstract}
Background: Desert frequently faces drought and famine condition affecting nutritional status.

Objectives: To assess impact of drought on nutritional status of school age children of rural population.

Design: Three stage sampling technique adopted covering 1497 school age children from 24 villages of Jodhpur district and examined at household level for their nutritional anthropometry, dietary and nutritional deficiencies.

Results: Growth retardation was observed. Wasting was in 22.4 percent children significantly higher in boys. Stunting and underweight was 36.6 and 43.9 percent (Less than Median-2SD). Stunting was higher in females than males in most of age groups though statistically insignificant. Vitamin A and B complex deficiencies were 1.4 and 2.7 percent respectively. Marasmus was 0.4 percent, significantly higher in boys $(0.7 \%)$ than girls. Overall mean calorie and protein intake deficit was high (61.9 \& 42.3\%). The comparison of present drought results with earlier studies in desert normal and desert drought conditions showed higher prevalence of protein energy malnutrition and deficiencies of calories and proteins.

Conclusions: Wasting was high indicating severity of malnutrition to be critical as prevalence of wasting is more than 15 percent (WHO) [1]. Protein energy malnutrition, vitamin A and B complex deficiencies, anemia along with deficit in calories and proteins in their diet was higher in comparison to non-desert areas, which may be due to the harsh environmental conditions in desert areas where drought occurs quite frequently affecting food intake of children. Supply of adequate calories and proteins should be stressed in ongoing nutrition programs.
\end{abstract}

Keywords: Desert; Nutrition; Dietary; Drought; Environment

\section{Introduction}

Desert areas very frequently face drought and famine condition where in nutrition plays a vital role in the community. During nutritional emergencies such as drought or famine, first relief priority is the provision of food to the community and the disease prevention through prompt attention to nutrition and to various aspects of environmental health (WHO) [1]. Food security implies that all people at all times have both physical and economic access to enough food for an active healthy life. WHO recommends an intake of more than $400 \mathrm{~g}$ of vegetables and fruits per day which provides protection? Attempts have been made to study the various aspects of nutrition and food security during famine, war, flood and economic crisis at international [2-5] and national [6-8] levels. In India, in desert areas of western Rajasthan, drought conditions occur quite frequently. Desert districts of Western Rajasthan had been the worst affected ones. During last century, the arid region experienced 47-62 percent droughts of varying intensities (CAZRI) [9] which had weakened the rural economy and largely eroded the coping capacity and economic potential of the people, with heavy livestock losses and reduced harvests leading to increased poverty and chronic malnutrition. This periodic cycle of scarce conditions, attributable to geomorphology and climatic characteristics of Thar Desert invariably affects the agricultural population residing in the desert by influencing their food intake. The cereals and millets contribute the maximum proportion of calories and protein intakes of the rural residents and in rural population of India, nearly 85 percent calories of the total daily calorie intake is consumed from the cereals and millets (DMRC drought study [6] 1987). However in desert residents this proportion is more than 85 percent. This proportion further increases during the outbreak of drought. DMR in 1987 conducted health and nutrition survey of drought affected parts of Rajasthan and revealed that school age children suffered from grade II i.e. severe degree of reduction of Fat fold at Triceps (FFT) based on frequency distribution of FFT values (Standard cut off values were applied for grading) and it was prevalent to an extant of 68.0 to 93.8 percent and male and females were equally affected. Calorie intake was reported significantly reduced in all age groups in all districts in comparison to Recommended dietary allowances (RDA) of Indian Council of Medical research [10] (ICMR). Clinical cases of PEM (1.5 to 2.6\%) were frequently seen in Barmer district in school age children. 
The survey was planned to study the impact of drought on nutritional status of school age children of rural population in desert area facing the drought conditions very frequently, the results of which would help in assessing the magnitude and extent of malnutrition in this area in school children which is not given due attention in research priorities. Hence the main objectives of this study was to assess the nutritional status of school age children of drought affected areas of Western Rajasthan by means of nutritional anthropometry, dietary intake as well as through clinical examination and to perform the time trend analysis of malnutrition and to suggest possible redressel mechanism. The results of this study have also been compared with the findings of 1987 drought survey and baseline health survey (conducted by DMRC) to assess the impact of drought on nutritional aspects responsible for enhancing the higher prevalence of various morbidities.

\section{Profile of the state of Rajasthan}

The great Indian desert or Thar, as it is commonly called, is spread over 2,85,680 $\mathrm{km}^{2}$ area between $22^{\circ} 30^{\circ} \mathrm{N}$ and $32^{\circ} 50^{\circ} \mathrm{N}$ and from $68^{\circ} 05^{\circ} \mathrm{E}$ to $75^{\circ} 45^{\circ} \mathrm{E}$. Within India it forms a part of the country's North West arid zone in the states of Rajasthan (69\%), Gujarat (21\%) and Punjab and Haryana (10\%). The greater part of desert has remained arid to hyper arid although. Summer tempera $\neg$ ture remains high, reaching up to $50{ }^{\circ} \mathrm{C}$ in May and June in some places. Dust storms are quite common with wind velocity above $50 \mathrm{~km} / \mathrm{h}$. The desert dweller have for centuries lived under harsh conditions with bare minimum of potable water which was fetched from far off places and stored as a precious treasure. Milk and milk products were available rather in plenty, but not drinking water. The dominant land use in the Thar had traditionally been grazing for livestock, supplemented by rain-fed agriculture, producing millets, pulses and oil seed crops (CAZRI [9]). Hence millet and wheat constituted their main food. In Rajasthan state of India, there are 32 districts out of which 12 districts represent desert areas (Thar Desert). The total population residing in rural areas of Thar desert of Rajasthan, is 1,39,62,000 settled in 12359 villages according to Census 1994 [11].

\section{Materials and Methods}

Rapid drought survey was conducted and data were collected on a total of 1497 school age children (complete in all senses) i.e. 5-15 years covering 24 villages belonging to 6 tehsils of Jodhpur district in May, 2003. The children were examined at household level following simple random sampling technique. At each individual level, information for Demography and Socio-Economic aspects had been collected by means of interview technique using pre tested schedules. Each individual was examined for the nutritional anthropometry, dietary intake and clinically for nutritional deficiency signs in order to assess the nutritional status. School age children were examined by trained Medical Anthropologist and Physician using standard equipment and methods. All the anthropometric measurements (height, weight, and fat fold at tricep) were taken following standard techniques mentioned in ICMR [12], TRS No.26 and Jellife [13]. According to WHO [1], the 'gold standard' in anthropometric assessment of children is weight-for-height, with the usual practice being to measure height of children. For nutritional anthropometry, the distribution of school age children according to weight-for-height using Standard Deviation classification [14] (SD classification) along with weight-for-age and height-for-age is provided. The internationally accepted WHO/NCHS $[1,14]$ reference values have been used and the overall prevalence of wasting which is an indicator for short duration malnutrition (less than Median - 2SD), stunting and underweight were calculated. For nutritional deficiency signs, classification of clinical signs that are considered to be of value in nutritional assessment and are believed to be of value in clinical assessment of malnutrition were considered, as prescribed by Jellife [13]. Each child was examined clinically from head to foot for nutritional deficiency signs. For dietary intakes, 24 hour recall method using oral questionnaire was adopted (ICMR [12], TRS No.26). As this survey was rapid drought survey due to urgency, only cereal and millets consumption survey were done as nearly 85 percent calories of the total daily calorie intake of the rural population of India is supplemented from the cereals and millets and in desert residents this proportion is more than 85 percent $[6,15]$.

The results of the present study were compared with the earlier surveys conducted in Jodhpur district by Desert Medicine Research Centre (DMRC) during drought conditions [6] (1987) and normal conditions [15] (Baseline health survey, 1986), besides, the normal non-desert conditions [15] (DMRC, 1986). Methodologies adopted in these surveys for diagnosing nutritional deficiency signs, anthropometry and dietary intake were same as in the present study. The comparisons were made between male and female for different age groups by applying Chi square and Proportion Test as per feasibility. For dietary analysis the mean calorie and protein intakes were compared with DMRC drought survey and Baseline health survey by applying t-test for difference of means (Snedecor \& Cochran) [16].

\section{Results}

Results revealed that 96.3 percent of covered population was Hindus and majority belonged to lower and middle income groups [17] (85.7\%) mainly involved in labor and famine work on drought relief work spots, followed by agriculture. Literacy status pertains to overall literacy. 57.8 percent women and 33 percent males were observed to be illiterate. Census [11] 2003 reported that overall 60.6 percent women and 39.4 percent males were illiterate in rural areas of Jodhpur district. 35.1 percent of total population belongs to Scheduled caste (SC) and 31 percent to other back caste (OBC).

The data for mean weight and height of present study have been compared with the NCHS standard (Figure 1-2). The growth retardation was observed in children. The means of weight and height of both the sexes in the present study were found to be low in comparison to NCHS standards at almost all ages. Table 1, 2 and 4 represents the percent distribution of school age children according under nutrition (weight-for-age, height-for-age and weight-for-height) by SD classification. 


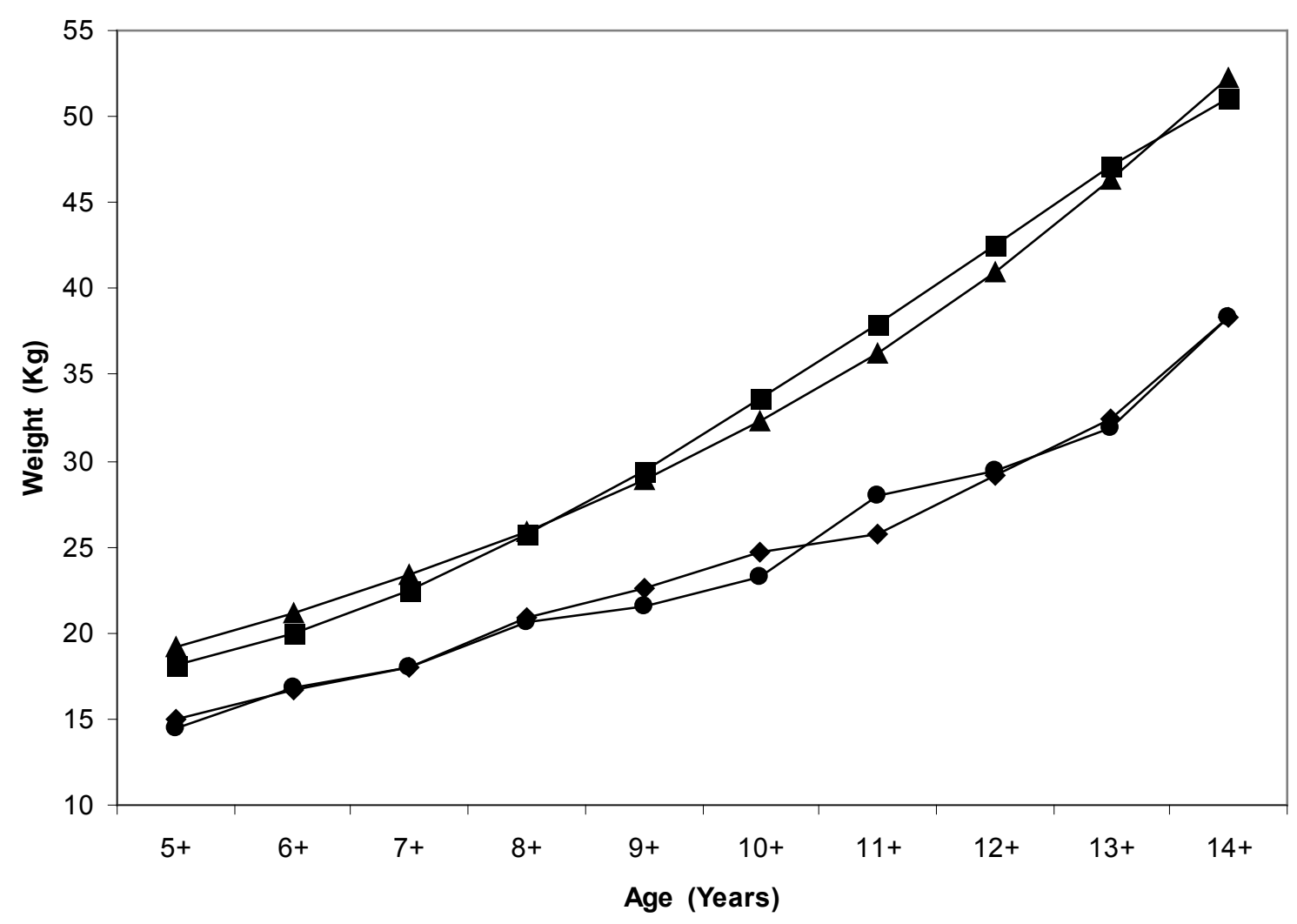

$\longrightarrow$ Present study-M $\longrightarrow$ Present study - F $\longrightarrow$ NCHS - M $\longrightarrow$ NCHS - F

Figure 1: Comparison of weights in present study with those of National Centre for Health Statistics (NCHS) references

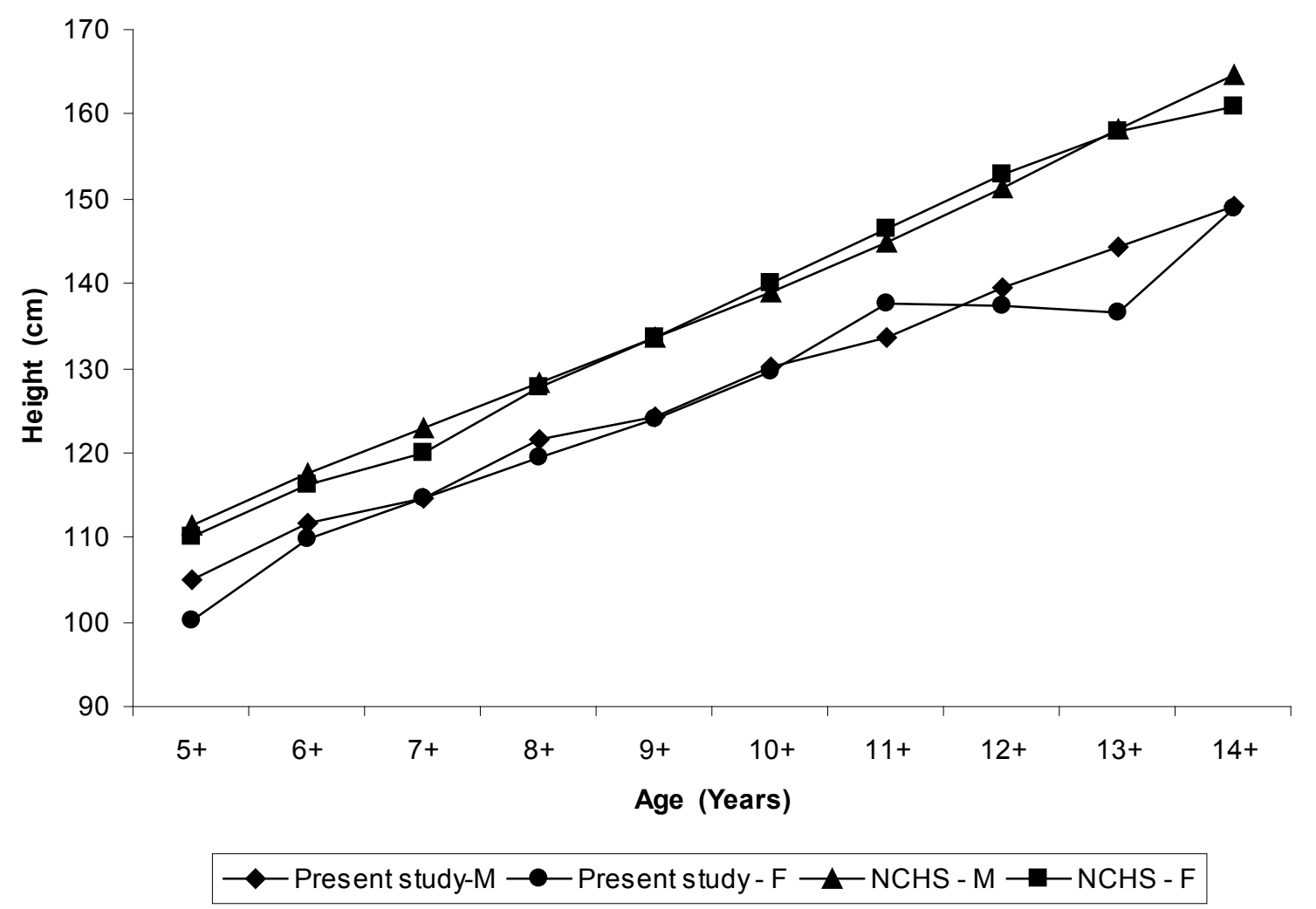

Figure 2: Comparison of heights in present study with those of National Centre for Health Statistics (NCHS) references 


\begin{tabular}{|c|c|c|c|c|c|c|c|c|}
\hline \multirow{2}{*}{$\begin{array}{c}\text { Age } \\
\text { Years }\end{array}$} & \multicolumn{9}{|c|}{ Boys } & \multicolumn{4}{c|}{ Girls } \\
\cline { 2 - 9 } & $\mathbf{N}$ & > Median-2SD & -3SD-2SD & < Median-3SD & $\mathbf{N}$ & > Median-2SD & -3SD-2SD & < Median-3SD \\
\hline $5+$ & 66 & 53.0 & 24.2 & 22.7 & 57 & 47.4 & 42.1 & 10.5 \\
\hline $6+$ & 75 & 61.3 & 29.3 & 9.4 & 74 & 66.2 & 21.6 & 12.2 \\
\hline $7+$ & 92 & 66.3 & 20.7 & 13.0 & 83 & 67.5 & 18.0 & 14.5 \\
\hline $8+$ & 90 & 68.9 & 22.2 & 8.9 & 91 & 72.5 & 18.7 & 8.8 \\
\hline $9+$ & 63 & 65.1 & 23.8 & 11.1 & 73 & 57.5 & 32.9 & 9.6 \\
\hline $10+$ & 136 & 66.2 & 27.2 & 9.6 & 107 & 63.6 & 27.1 & 9.3 \\
\hline $11+$ & 73 & 71.2 & 19.2 & 6.6 & 53 & 66.0 & 28.3 & 5.7 \\
\hline $12+$ & 93 & 65.6 & 28.0 & 6.4 & 73 & 61.6 & 31.6 & 6.8 \\
\hline $13+$ & 58 & 60.4 & 24.1 & 15.5 & 32 & 46.9 & 37.5 & 15.6 \\
\hline $14+$ & 46 & 58.7 & 28.3 & 13.0 & 54 & 50.0 & 31.5 & 18.5 \\
\hline $5-15$ & 792 & 64.4 & 24.7 & 10.9 & 697 & 62.3 & 26.5 & 11.2 \\
\hline
\end{tabular}

${ }^{*} \mathrm{P}<0.05$ between $\mathrm{B} \& \mathrm{G}$

Table 1: Height for Age - Percent distribution of children according to Standard Deviation classification

\begin{tabular}{|c|c|c|c|c|c|c|c|c|}
\hline \multirow{2}{*}{$\begin{array}{c}\text { Age } \\
\text { Years }\end{array}$} & \multicolumn{9}{|c|}{ Boys } & \multicolumn{4}{c|}{ Girls } \\
\cline { 2 - 10 } & $\mathbf{N}$ & > Median-2SD & -3SD-2SD & < Median-3SD & $\mathbf{N}$ & > Median-2SD & -3SD-2SD & < Median-3SD \\
\hline $5+$ & 66 & 68.2 & 27.3 & 4.5 & 57 & 84.2 & 15.8 & 0.0 \\
\hline $6+$ & 75 & 65.4 & 29.3 & 5.3 & 74 & $86.5^{* *}$ & 13.5 & 0.0 \\
\hline $7+$ & 92 & 72.7 & 37.3 & 0.0 & 83 & 77.1 & 19.3 & 3.6 \\
\hline $8+$ & 90 & 77.8 & 21.1 & 1.1 & 91 & 84.6 & 15.4 & 0.0 \\
\hline $9+$ & 64 & 84.4 & 14.1 & 1.5 & 71 & 78.9 & 21.1 & 0.0 \\
\hline $10+$ & 129 & 69.0 & 27.1 & 3.9 & 105 & 72.4 & 23.8 & 3.8 \\
\hline $11+$ & 70 & 68.6 & 25.7 & 5.7 & 46 & 80.4 & 19.6 & 0.0 \\
\hline $12+$ & 79 & 84.8 & 13.9 & 1.3 & 55 & 87.3 & 12.7 & 0.0 \\
\hline $13+$ & 30 & 83.3 & 16.7 & 0.0 & 17 & $100^{* *}$ & 0.0 & 0.0 \\
\hline $14+$ & 11 & 100 & 0.0 & 0.0 & 18 & 83.3 & 11.1 & 5.6 \\
\hline $5-15$ & 706 & 74.4 & 22.9 & 2.7 & 617 & $81.4^{* *}$ & 17.3 & 1.3 \\
\hline
\end{tabular}

${ }^{*} \mathrm{P}<0.01,{ }^{*} \mathrm{P}<0.05$ between $\mathrm{B} \& \mathrm{G}$

Table 2: Weight for Height - Percent distribution of children according to Standard Deviation classification

\begin{tabular}{|c|c|c|c|c|}
\hline \multirow{3}{*}{$\begin{array}{l}\text { Clinical Nutritional } \\
\text { Deficiency Signs }\end{array}$} & \multicolumn{3}{|c|}{$\begin{array}{l}\text { Present Study (\%) } \\
\qquad \mathrm{N}=1497\end{array}$} & \multirow{3}{*}{$\begin{array}{l}\text { Non desert } \\
(\%) \mathrm{N}=549\end{array}$} \\
\hline & \multicolumn{2}{|c|}{$5-15$ years } & \multirow[t]{2}{*}{ G.T } & \\
\hline & B & G & & \\
\hline \multicolumn{5}{|c|}{ Protein calorie Malnutrition } \\
\hline Marasmus & 0.7 & $0.2^{\star \star}$ & 0.4 & NA \\
\hline \multicolumn{5}{|c|}{ Vitamin A Deficiency } \\
\hline Night Blindness & 0.4 & 0.4 & 0.4 & 0.0 \\
\hline Bitot Spot & 1.0 & 1.1 & 1.0 & $0.1^{*}$ \\
\hline \multicolumn{5}{|c|}{ Vitamin B Complex deficiency } \\
\hline Angular Stomatitis & 1.1 & 0.7 & 0.9 & 0.7 \\
\hline Cheliosis & 1.1 & 0.7 & 0.9 & 0.4 \\
\hline Glossitis & 1.0 & 0.9 & 0.9 & 0.0 \\
\hline \multicolumn{5}{|c|}{ Vitamin C deficiency } \\
\hline Gums Bleeding & 1.5 & 1.3 & 1.4 & NA \\
\hline Teeth caries & 5.5 & 4.1 & 4.8 & $16.9^{* *}$ \\
\hline Mottled Enamel & 21.1 & $17.3^{\star}$ & 19.2 & $8.3^{\star *}$ \\
\hline Anemia: pallor conjuctiva & 36.3 & $30.8^{\star}$ & 33.5 & $2.2^{\star *}$ \\
\hline
\end{tabular}

${ }^{*} \mathrm{P}<0.01{ }^{* *} \mathrm{P}<0.05$

Table 3: Percent prevalence of Nutritional Deficiency Signs 


\section{Weight for Age}

In general, about 43.9 percent of the school age children had underweight, (less than Median - 2SD) while the prevalence of severe underweight (less than Median - 3SD) was found to be about 7.1 percent. Age wise analysis of overall under nutrition revealed that highest underweight was found in 5 years age groups followed adolescent age group i.e. 10-13 years (Table 4). Underweight was higher in boys than girls in all age groups except 9-10 years though statistically insignificant.

\begin{tabular}{|c|c|c|c|c|c|c|c|c|}
\hline \multirow{2}{*}{$\begin{array}{c}\text { Age } \\
\text { Years }\end{array}$} & \multicolumn{4}{|c|}{ Boys } & \multicolumn{4}{c|}{ Girls } \\
\cline { 2 - 10 } & $\mathbf{N}$ & > Median-2SD & -3SD-2SD & <Median-3SD & $\mathbf{N}$ & > Median-2SD & -3SD-2SD & < Median-3SD \\
\hline $5+$ & 66 & 40.9 & 39.4 & 19.7 & 57 & 47.4 & 42.9 & 10.5 \\
\hline $6+$ & 75 & 48.0 & 36.0 & 16.0 & 74 & $68.9^{*}$ & 23.0 & 8.1 \\
\hline $7+$ & 92 & 42.4 & 43.5 & 14.1 & 83 & 57.8 & 33.7 & 8.5 \\
\hline $8+$ & 90 & 63.3 & 27.8 & 8.9 & 91 & 69.2 & 28.6 & 2.2 \\
\hline $9+$ & 63 & 66.7 & 30.1 & 3.2 & 73 & 53.4 & 41.1 & 5.5 \\
\hline $10+$ & 136 & 52.9 & 42.7 & 4.4 & 107 & 48.6 & 43.0 & 8.4 \\
\hline $11+$ & 73 & 54.8 & 41.1 & 4.2 & 53 & 62.3 & 37.7 & 0.0 \\
\hline $12+$ & 93 & 51.6 & 46.2 & 2.2 & 73 & 61.6 & 31.5 & 6.9 \\
\hline $13+$ & 58 & 50.0 & 43.1 & 6.9 & 32 & 56.3 & 43.7 & 0.0 \\
\hline $14+$ & 46 & 63.0 & 37.0 & 0.0 & 54 & 74.1 & 18.5 & 7.4 \\
\hline $5-15$ & 792 & 52.9 & 39.1 & 8.0 & 697 & 59.7 & 34.1 & 6.2 \\
\hline
\end{tabular}

${ }^{*} \mathrm{P}<0.05$ between $\mathrm{B} \& \mathrm{G}$

Table 4: Weight for Age - Percent distribution of children according to Standard Deviation classification

\section{Height for Age}

It signifies a slowing of skeletal growth and is a principal indicator of long-term nutritional experience or growth impairment caused by malnutrition in the past (WHO) [18]. The overall prevalence of stunting (less than Median - 2SD) was about 36.6 percent with the extant of severe stunting (less than Median - 3SD) being about 11.0 percent. Age wise analysis revealed that 5 years age group and adolescent group children (9-14 years) suffered more from stunting. Severe stunting was found higher in girls (11.2\%) than boys (10.9\%) though statistically insignificant. Overall stunting is higher in girls than boys in most of age groups though statistically insignificant.

\section{Weight for Height}

The overall prevalence of wasting (less than Median - 2SD), an indicator of short duration malnutrition was about 22.4 percent with the extant of severe wasting (less than Median - 3SD) being about 2 percent. Age wise, 10 to 11 years age group suffered more from wasting (29.3 \& 25.5\%). Wasting is higher in boys than girls in most of age groups except in 9 years age group.

Reduction in calorie consumption is likely to affect the fat deposits. It was observed that 25.2 percent school age children suffered from mild to moderate deficit in fat fold at triceps (FFT) and 64.6 percent suffered severally from FFT deficit which was found high. The results of the present study when compared with earlier drought survey of Jodhpur district, it was observed that 18.9 percent school age children suffered from mild to moderate deficit in fat fold at triceps (FFT) and 69 percent suffered severally from FFT deficit which was found high.

Table 3 shows the analysis of nutritional deficiency signs (Standard meth $\neg$ ods has been adopted as prescribed in ICMR TRS No. 26 and Jellife) [12,13]. The overall prevalence of anemia was observed to be 33.5 percent, diagnosed on the basis of conjunctival pallor and platynichia and koilonichia. Prevalence of marasmus was 0.4 percent, significantly higher in boys (0.7\%) than girls $(\mathrm{P}<0.05)$. Regarding vitamin A deficiency, overall prevalence of bitot spot was 1.0 percent and night Blindness was 0.4 percent. Regarding vitamin B complex deficiency, overall prevalence of angular stomatitis, cheliosis, and glossitis was observed to be 0.9 percent. Vitamin C deficiency was observed 1.4 percent (gums bleeding). The teeth caries and mottling of enamel were observed to be 4.8 and 19.2 percent respectively.

The results of the present study when compared with earlier drought survey of Jodhpur district, it was observed that prevalence of vitamin A deficiency and B complex deficiencies were found highly reduced in comparison to 1987 study i.e. bitot spot reduced from 42.8 to $1.0 \%$ and vitamin B complex deficiency from 81.9 to $2.7 \%$. Overall prevalence of anemia was also reduced to 33.5 percent in comparison to earlier study [6] (72.1\%).

Table 3 also shows the comparison of data of nutritional deficiency signs in studied population with non desert data of Jaipur district. (DMRC [15], 1986 - Jaipur district in Rajasthan is having area of $14068 \mathrm{sq}$. km. with population density of 243/sq km. Average humidity during the year was $54.2 \%$ and total annual rainfall $61.57 \mathrm{~cm}$. This data was collected in 1986-87 by Desert Medicine Research Centre and criteria being used to define and diagnose each illness was same as in the present study). This table shows that vitamin A and B complex deficiencies along with anemia, have been observed significantly higher in the present studied as compared to the non desert areas. This may be due the harsh environmental conditions and related socio-economic factors. 
Nearly 85 percent calories of the total daily calorie intake of the rural population of India is supplemented from the cereals and millets and in desert residents this proportion is more than 85 percent (It is based on the evidence of the results of earlier studies Desert drought [6], 1987 and Desert normal and Non Desert, 1986 [15] where overall calorie and protein intake was higher in Desert Drought study (1987) than Desert Normal and Non Desert study (1986) though in Desert Drought study (1987), only cereals and millets consumption survey was carried out whereas in Desert Normal and Non Desert study (1986), calorie and protein intakes was calculated from full information on whole diets consumed by population. This indicates that in desert area total daily calorie intake of rural population is supplemented mainly from cereals and millets). It was a rapid drought survey. Due to urgency and shortage of time, only cereal and millets consumption survey was carried out. Table 5 showed that mean calorie intake was very poor in comparison to recommended dietary allowances (RDA), Indian Council of Medical Research (ICMR) [10] i.e. 862.2 and 845.6 calories in males and females respectively. Calorie deficit was observed higher i.e. 61 percent. In the present study, mean calorie intake (845-862 calories) was observed to be significantly low $(\mathrm{P}<0.01)$ in comparison to earlier studies $[6,15]$ in drought and normal conditions, which might be responsible for the high prevalence of protein calorie malnutrition (PCM) in the present study (Table 5).

\begin{tabular}{|c|c|c|c|c|}
\hline \multirow{2}{*}{$\begin{array}{c}\text { Different } \\
\text { Surveys }\end{array}$} & \multicolumn{2}{|c|}{ Mean calorie intakes } & \multicolumn{2}{c|}{ Mean protein intakes } \\
\cline { 2 - 5 } & Boys & Girls & Boys & Girls \\
\hline $\begin{array}{c}\text { Present drought } \\
\text { study, 2003 }\end{array}$ & $\begin{array}{c}862.2^{\star} \pm 400.42 \\
(774)\end{array}$ & $\begin{array}{c}845.6^{*} \pm 645.82 \\
(703)\end{array}$ & $\begin{array}{c}30.3^{*} \pm 14.08 \\
(774)\end{array}$ & $\begin{array}{c}29.7^{\star} \pm 22.70 \\
(703)\end{array}$ \\
\hline Desert drought 1987 & $\begin{array}{c}1588 \pm 526.4 \\
(376)\end{array}$ & $\begin{array}{c}1567 \pm 478.3 \\
(147)\end{array}$ & $\begin{array}{c}52.9 \pm 17.54 \\
(376)\end{array}$ & $\begin{array}{c}52.2 \pm 16.61 \\
(147)\end{array}$ \\
\hline Desert Normal & 1795 & 1412 & 58.9 & 47.3 \\
$(198)$ & $(114)$ & 59.5 & $(114)$ \\
\hline No86 & $(138)$ & 1817 & $(65)$ & 57.0 \\
$(1889$ & $(51)$ & $\mathbf{5 3 . 0}$ & $\mathbf{5 1 . 0}$ \\
\hline
\end{tabular}

$*(\mathrm{P}<0.01)()$ Values in the parenthesis are number covered

*RDA-Recommended Dietary Allowances, ICMR.

Table 5: Comparative table of mean calorie intakes and mean protein intakes in different surveys according gender

Deficit in the mean protein intake was also observed. Overall protein intake was 30.3 and 29.7 gm in males and females respectively, which were lower in comparison to recommended dietary allowances (RDA), Indian Council of Medical Research (ICMR) [10]. Overall mean protein intake deficit was 42.3 percent. In the present study, mean protein intake (29-30 gm) was observed significantly low $(\mathrm{P}<0.01)$ in comparison to earlier studies $[6,15]$ which might be responsible for the increase of prevalence of protein calorie malnutrition in the present study (Table 5).

The frequency distribution of protein intake revealed that 6 to 50 percent children had protein intake less than 22.5 gm which was nearly half of the RDA, ICMR [10] values. Percentage of protein deficit was high.

Table 5 also showed the comparison of data of calorie and protein intakes with non- desert area [15]. The overall deficit in calories and proteins intakes was significantly higher $(\mathrm{P}<0.01)$ in the present studies as compared to non-desert areas [15]. This may be due to the typical harsh environmental conditions of desert where children are exposed to extreme environmental conditions, rapidly occurring drought leading to poor economy affecting their dietary intake in turn.

\section{Discussion}

Wasting, an indicator of short duration malnutrition, was 22.4 percent indicating severity of malnutrition to be critical as prevalence of wasting (\% below Median - 2SD) is more than 15 percent (cut offs given by WHO) [1]. Growth retardation was observed in children. In all age groups, means of weight and height of the studied children (both the sexes) were low in comparison to NCHS standards. Height for age signifies a slowing of skeletal growth and is a principal indicator of long-term nutritional experience or growth impairment caused by malnutrition in the past (WHO) [18]. Stunting (long duration malnutrition) was observed 36.6 percent and underweight 43.9 percent. Stunting was higher in females than males in most of age groups, which might be due to the fact that girls were not being given proper care as reported earlier (Singh et al.) [19,20], whereas wasting and underweight was higher in boys than girls in all age groups except 9-10 years though statistically significant only in few age groups indicating boys suffered more from short term malnutrition. Extant of malnutrition in children was highest in 5 years age group followed by adolescent age groups i.e. 10-13 years which may be due to the fact that body requirement is more during adolescence period.

Most of the studies reported in literature are on preschoolers. Wasting, stunting and underweight were observed higher in the present study in comparison to other studies [4,7,21]. In Ethiopia study [2] (2001), 51.1 percent of children were below - 2 Z-score and 26.3 were below - $3 \mathrm{Z}$-score for height. The prevalence rate of underweight was 46 percent and the wasting was 11 percent. In NIN studies [7,21], wasting was observed 26.2 percent in 2000 and 15.4 percent in preschool children in 2003. In study of Malasiya [22], 37.5 percent school children were underweight, $43.6 \%$ were stunted and Wasting was 5.6 percent. 
The results of the present study have shown that school age children of desert area suffered from protein calorie malnutrition, vitamin $A$ and $B$ complex deficiencies along with anemia. The prevalence of protein calorie malnutrition was higher in the present study in comparison to the earlier drought study in Jodhpur district ( DMRC) [6], whereas, vitamin A and B complex deficiencies along with anemia have shown declining trend, which may be due to the supply of vitamin A and Iron by State Government. Present study children showed higher deficit in calories and proteins intake in their diet in comparison to earlier drought study which may be responsible for higher prevalence of protein calorie malnutrition in present studied children. This may be due to the fact that there was almost failure of monsoon for consecutive 3 years leading to reduced harvests and poor economy further declining the availability and accessibility of food to the community. Wheat and millets were the staple diet in this area. But due to crop failure, they mainly depended on wheat supplied in lieu of work done program. Green leafy and other vegetables were not available. Local desert dried vegetables/foods such as Ker (Capparis deciduas), Sangri (Prosopis cinereria) and Kumathiya (Acacia senegal) were consumed. There was no local production of agricultural and animal products yield during drought leading to shortage of food grains, fodder and increased unemployment of the labour with direct economic consequences along with food insecurity leading to malnutrition.

Study showed that malnutrition is existing not only in preschoolers but also in school age children to high extant in desert areas though the extant is more in preschoolers [23] (wasting 28\%). Vitamin A and B complex deficiencies along with anemia were significantly higher in desert area population as compared to non-desert area (DMRC) [15] as well as from other studies from rural India (Vijayaraghvan \& Hanumantha Rao [24] ; Mohapatra et al.[8]), where protein calorie malnutrition was observed to be 0.2 and 4.5 percent respectively in preschoolers. Overall calorie and protein deficit was observed higher in present studies in comparison to non-desert area (DMRC) [15] as well as other parts of country (Vijayaraghvan \& Hanumantha Rao) [24]. It might be due to the harsh environmental conditions of desert areas where drought occurs quite frequently and adversely affects the economy, largely eroded the coping capacity and economic potential of the people, with heavy livestock losses and reduced harvests leading to increased poverty and poor food intake of the inhabitants, which in turn might be responsible for higher protein deficit in the studied group. Due to inadequate consumption of daily food the children were suffering from wasting and protein calorie malnutrition. Efforts should be made to incorporate the measures such as ensuring the supply of adequate calories and proteins to all age groups not only to under five children but also to school age children through the ongoing nutrition programs in order to improve the food security. Attention should also be given to school age children group in desert areas in the field of nutrition.

\section{Acknowledgement}

The authors express their deep sense of gratitude to the Director-in-charge, DMRC, Jodhpur for guidance and providing facilities. All the authors were involved in the set up of study, in the study itself, collection of data, analysis and writing of the manuscript etc. The authors declare that they have no conflict regarding this paper and have had no involvements that might raise the question of bias in the work reported or in the conclusions, implications or opinions stated. It was funded by DMRC, Jodhpur.

\section{References}

1. World Health Organisation (WHO) (2000) The management of nutrition in major emergencies. Geneva, WHO.

2. Hatloy A, Hallund J, Diarra MM, Oshaug A (2000) Food variety, socioeconomic status and nutritional status in urban and rural areas in Koutiala (Mali). Public Health Nutr 3: 57-65.

3. Soekirman (2001) Food and nutrition security and the economic crisis in Indonesia. Asia Pac J Clin Nutr 10: S57-61.

4. Kaluski DN, Ophir E, Amede T (2002) Food security and nutrition - the Ethiopian case for action. Public Health Nutr 5: 373-81.

5. Kaiser LL, Melgar-Quionnez HR, Lamp CL, Johns MC, Sutherlin JM, et al. (2002) Food security and nutritional outcomes of preschool- age Mexican-American children. J Am Diet Assoc 102: 924-9.

6. Desert Medicine Research Centre (DMRC) (1987) Health and Nutrition survey of Drought affected parts of Rajasthan. Final Report Part II. DMRC, Jodhpur, 47.

7. Vijayaraghavan K, Hanumanthao Rao D, Sarma KVR, Brahmam GNV (2000) Diet and Nutrition situation in Drought affected areas of Rajasthan, National Institute of Nutrition, ICMR, Hyderabad.

8. Mohapatra, A, Geddam JJ, Marai,N, Murmu B, Mallick G, et al. (2000) Nutritional status of preschool children in the drought affected Kalahandi district of Orissa. Indian J Med Res 111: 90-4.

9. Central Arid Zone Reaserch Institute (CAZRI) (2001) Symposium on Impact of Human Activities on Thar Desert environment organised by Arid Zone Research Association of India, held at CAZRI from 15-7.

10. Indian Council of Medical Research (ICMR) (1989) Nutrient requirements and recommended dietary allowances for Indians. New Delhi: ICMR 129.

11. Directorate of Economics \& Statistics (1994,2003) Census: Basic statistics, Rajasthan, Jaipur: Directorate of Economics \& Statistics, Rajasthan.

12. Indian Council of Medical Research (ICMR) (1977) Studies on preschool children. ICMR Tech. Rep. Ser. No 26 New Delhi: ICMR, 62.

13. Jelliffe DB (1967) The assessment of the nutritional status of the community. Geneva: WHO.

14. World Health Organization (WHO) (1983) Measuring changes in Nutritional status, Geneva, WHO.

15. Desert Medicine Research Centre (DMRC) (1986) Baseline health survey in three districts of Rajasthan. Final Report, Jodhpur: DMRC, 183.

16. Snedecor GW, Cochran WG (1989) Statistical methods. 8th Edtn, University Press 593. 
17. Indian Council of Medical Research (ICMR) (1990) A national collabo $\neg$ rative study of identification of high risk families mothers and outcome of their offsprings with particular reference to the problem of maternal nutrition, LBW, peri-natal and infant morbidi $\neg$ ty in rural and urban slum communities. An ICMR Task force study, ICMR, New Delhi 136.

18. World Health Organisation (WHO) working group (1986) Use and interpretation of anthropometric indicators of nutritional status. Bull World Health Organ 64: 929-41.

19. Singh MB, Haldiya KR, Yadav SP, Lakshminarayana J, Mathur ML, et al. (1996) Nutritional status of school age children of salt-workers in Rajasthan. Indian J Med Res 103: 304-9.

20. Singh MB, Haldiya KR, Lakshminarayana J (2002) Morbidity Pattern and its association with malnutrition in preschool children in desert areas of Rajasthan, India. J Arid Environ 51: 461-8.

21. National Institute of Nutrition (NIN) (2003) Diet and nutrition in drought affected areas of Rajasthan. Hyderabad: NIN 15.

22. Al-Mekhlafi HM, Mahdy, MA, Sallam AA, Arffin,WA, Al-Mekhlafi AM, et al. (2011) Nutritional and socio-economic determinants of cognitive function and educational achievement of aboriginal school children in rural Malaysia. Br J Nutr 106: 1100- 6.

23. Singh MB, Fotedar R, Lakshminarayana J, Anand PK (2006) Studies on the nutritional status of under five children in drought affected desert area of Western Rajasthan, India. Public Health Nutr 9: 961- 7.

24. Vijayaraghvan K, Rao DH (1998) Diet and Nutrition situation in rural India. Indian J Med Res 108: 243-53.

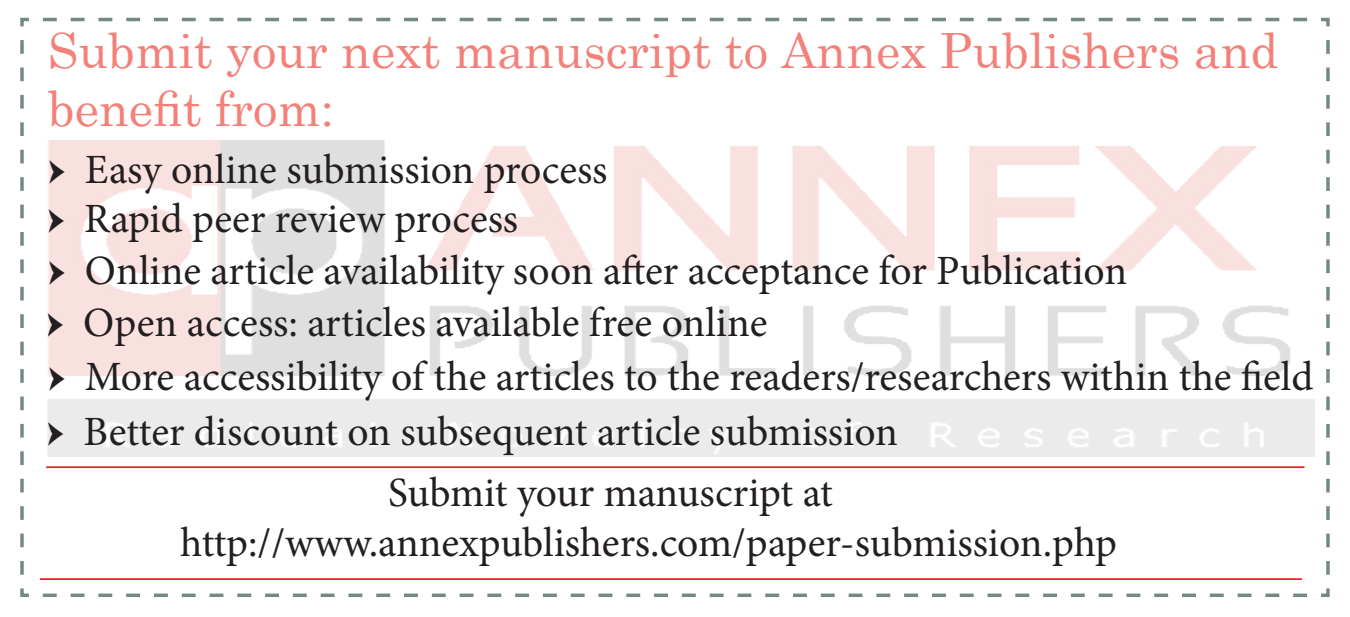

